\title{
ANALISIS PERBEDAAN MINAT IBU RUMAH TANGGA DALAM MEMBUAT PERENCANAAN KEUANGAN MENURUT KARAKTERISTIK KELUARGA DI KOTA PEKANBARU
}

\author{
Elisanovi, SE.MM.AK.CA
}

\begin{abstract}
This study aims to determine the level of public financial literacy in the city of Pekanbaru by examining whether there are differences in interest in making family financial planning according to family characteristics in the city of Pekanbaru. The population in this study is the number of households in the city of Pekanbaru amounting to 213,795 households. The sample obtained was 400 housewives as respondents using the proportionate stratified random sampling method. Independent variable $(X)$ is family characteristics in the form of work (X1) and number of children (X2), and the dependent variable is interest $(Y)$. The research instruments used were questionnaires and interviews as data support. And for hypothesis testing using chi square data analysis. The results of the study show that based on work and the number of children there are differences in interest in making family financial planning
\end{abstract}

Keywords: interests, employment, number of children

\begin{abstract}
ABSTRAK
Penelitian ini bertujuan untuk mengetahui tingkat literacy keuangan masyarakat di kota Pekanbaru dengan mengkaji apakah terdapat perbedaan minat membuat perencanaan keuangan keluarga menurut karakteristik keluarga di kota Pekanbaru. Populasi dalam penelitian ini adalah Jumlah rumah tangga di kota Pekanbaru sebesar 213.795 kepala keluarga. Sampel yang diperoleh sebanyak 400 orang ibu rumah tangga sebagai responden dengan menggunakan metode pengambilan sampel proportionate stratified random sampling. Variabel independen $(X)$ adalah karakteristik keluarga berupa pekerjaan (X1) dan jumlah anak (X2), serta variabel dependen adalah minat $(Y)$. Instrumen penelitian yang digunakan adalah kuisioner dan wawancara sebagai support data. Dan untuk pengujian hipotesis menggunakan analisis data chi square. Hasil kajian menunjukkan bahwa berdasarkan pekerjaan dan jumlah anak terdapat perbedaan minat membuat perencanaan keuangan keluarga
\end{abstract}

Kata Kunci : minat, pekerjaan, jumlah anak 


\section{PENDAHULUAN}

Untuk mensosialisasikan pentingnya memiliki perencanaan keuangan dalam keluarga sebagai sasaran yang tepat adaalah para ibu rumaha tangga. Sebagaimana diketahui ibu rumah tangga merupakan orang yang sangat berperan dalam menyusun perencanaan keuangan keluarga. Selain itu ibu rumah tangga memiliki berbagai macam karakteristik yang berbeda. Tingkat pendidikan, jumlah anak dan profesi ibu rumah tangga sangat mempengaruhi dalam menyusun perencanaan keuangan keluarga.

Penelitian yang dilakukan oleh Meilyanti, Henny, dan Yohnson dengan judul "Analisis Perbedaan Minat Membuat Perencanaan Keuangan Keluarga Menurut Karakteristik Keluarga Di Surabaya” memberikan gambaran keadaan minat keluarga di Surabaya terhadap perencanaan keuangan. Hasil penelitian tersebut membuktikan bahwa minat keluarga di Surabaya yang berpendidikan tinggi setara S1 lebih besar dibandingkan keluarga yang berpendidikan menengah setara SMU (Sekolah Menengah Umum) .Jadi faktor pendidikan keuangan sangat penting agar seseorang tertarik pada perencanaan keuangan .

Penelitian lain yang dilakukan oleh Martha Henn McCormick membahas tentang efektifitas pendidikan pada usia remaja karena remaja paling sering merasakan dampak kompleksitas keuangan keluarga. Studi ini berusaha menggambarkan pendidikan keuangan pada generasi muda saat ini dan memberi arah kedepannya agar dapat membuat keputusan keuangan yang tepat. Penelitian oleh (Xiao el.al, 2008; Mandell dan Klein, 2009) menyimpulkan bahwa cara terbaik untuk memperbaiki perilaku di usia dewasa adalah dengan cara mengajarkan perilaku yang baik sejak kecil, termasuk perilaku keuangan (financial behavior). Sementara di Indonesia sendiri pendidikan keuangan pribadi (personal finance) masih jarang ditemui baik itu di sekolah dasar sampai perguruan tinggi.

\section{TINJAUAN LITERATUR}

\section{Pengertian Perencanaan Keuangan}

Menurut Kamus Besar Bahasa Indonesia perencanaan keuangan adalah disiplin manajemen kekayaan yang berlaku dengan kebutuhan unik dan keprihatinan individu masing-masing. Secara sederhana perencanaan keuangan disefenisikan 
sebagai suatu proses untuk mencapai tujuan hidup melalui pengaturan keuangan yang sesuai. Menurut Bertisch dalam Yohnshon (2004) Financial planning can be defined as the carefull preparation and coordination of plans necessary to prepare for fiture financial needs and goals. It is not investment analisys. It involves mapping strategies to achieve your defined goals. Menurut Kapoor (2004) Personal Financial Planning is the process of managing your money to achieve personal economic satisfaction.

Senduk (2009) menyatakan bahwa perencanaan keuangan juga didefinisikan sebagai proses merencanakan keuangan untuk mencapai tujuan-tujuan keuangan jangka pendek maupun jangka panjang.

\section{Keluarga dan uang.}

Hadisubrata (1990) mengartikan keluarga sebagai unit sosial terkecil didalammasyarakat, yang terdiri dari ayah, ibu dan anak-anak yang belum menikah (nuclear family)

Kestabilan ekonomi di dalam keluarga merupakan salah satu faktor yang ikut menentukankebahagian di dalam keluarga, karena penghasilan yang tidak mencukupi kebutuhan hidup dapatmerupakan penyebab utama terjadinya pertengkaran di dalam sebuah keluarga. Terjadinya ketidakstabilan dalam perekonomian keluarga bukan saja karena penghasilan yang tidak cukup,tetapi karena keluarga tersebut kurang bijaksana di dalam membelanjakan uang.

Oleh karena itu, Hadisubrata (1990) menyatakan bahwa :

"Agar ekonomi keluarga stabil maka di dalam keluarga tersebut perlu untuk membuat rencana anggaran belanja, dan mengembangkan sikap-sikap tertentu yang mendukungterwujudnya kestabilan ekonomi keluarga, antara lain keterbukaan antara suami dan istridalam hal keuangan karena dalam keluarga tidak ada "uangmu" atau "uangku" yang ada hanyalah "uang kita"

Sikap lain yang berhubungan dengan pelaksanaan rencanakeuangan keluarga adalah sikap disiplin dalam melaksanakan apa yang telah direncanakan sehingga tidak akan terjadi banyak penyimpangan dari apa yang telah direncanakan.Latar belakang keluarga, nilai-nilai yang dianut dalam keluarga dan kebudayaan yang dimiliki mempengaruhi cara berpikir seseorang mengenai uang dan pengelolaannya".

\section{Pentingnya Perencanaan Keuangan di dalam Keluarga}


Pentingnya perencanaan keuangan dalam keluarga bukan hanya bagi keluarga yang berpenghasilan tinggi atau kaya namun juga sangat diperlukan bagi keluarga yang berpenghasilan rendah, yang membedakannya adalah dari segi pengalokasian penghasilan tersebut.Menurut Senduk (2009) beberapa alasan mengapa keluarga memerlukan perencanaan keuangan :

1. Adanya tujuan keuangan yang ingin dicapai.

2. Tingginya biaya hidup saat ini.

3. Naiknya biaya hidup dari tahun ketahun.

4. Keadaan perekonomian tidak akan selalu baik.

5. Fisik manusia tidak akan selalu sehat.

6. Banyaknya alternatif produk keuangan.

Fenomena saat ini yang terdengar adalah banyaknya orang yang mengeluh tentang kondisi keuangan yang morat-marit. Dengan sikap hidup yang konsumtif mengakibatkan sesorang memiliki hutang yang jumlahnya melebihi pendapatannya atau bahkan asetnya. Sehingga pengelolaan keuangan yang salah menjadi akar permasalahannya. Apalagi banyak yang tidak memiliki perencanaan keuangankarena perencanaan keuangan merupakan aktivitas mutlak yang harus dilakukan oleh setiap orang. Sehingga hal inilah yang membedakan orang yang mengalami kesulitan likuiditas dengan orang bisa menikmati hidupnya.

\section{Minat Membuat Perencanaan Keuangan Keluarga}

Minat membuat perencanaan keuangan adalah ketertarikan atau perasaan suka yang dimiliki keluarga terhadap perencanaan keuanganyang mendorong keluarga untuk mengetahui, mempelajari lebih dalam dan melakukannya, hingga pada akhirnya keluarga mapan akan tercapai. Dalam kamus psikologi minat diartikan sebagai perasaan yang menyatakan bahwa suatu aktivitas, pekerjaan, atau obyek itu berharga atauberarti bagi individu dan suatu keadaan motivasi yang menuntun tingkah laku menuju satu arah atau sasaran tertentu.

Menurut Gregory (1992), "interest is a preference for particular ideas, activities, and objects; value involves the importance or worth attached to those ideas, activitiesand objects". Pernyataan ini dapat diartikan bahwa minat adalah perasaan lebih 
suka/tertarikterhadap ide-ide, aktivitas, atau objek; suatu nilai yang penting dan berharga yang terdapat padaide-ide, aktivitas dan obyek-obyek.

Sedangkan menurut Winkel (1986) minat adalah "Kecenderungan yang menetap dalamsubyek untuk merasa tertarik pada bidang atau hal tertentu dan merasa senang berkecimpungdalam bidang itu".

\section{Literasi Keuangan dan Perencanaan Keuangan}

Menurut buku pedoman Strategi Nasional Literasi Keuangan Indonesia (OJK, 2013), yang dimaksud dengan literasi keuangan adalah "Rangkaian proses atau aktivas untuk meningkatkan pengetahuan (knowledge), Keyakinan (Confidence) dan Keterampilan (Skill) konsumen dan masyarakat luas sehingga mereka mampu mengelola keuangan yang lebih baik."

Literasi keuangan juga bermakna bahwa seorang individu yang cakap (literate) adalah seseorang yang memiliki sekumpulan keahlian dan kemampuan yang membuat orang tersebut mampu memanfaatkan sumber daya yang ada untuk mencapai tujuan. Kecakapan (literacy) merupakan hal penting yang harus dimiliki untuk mencapai tujuan-tujuannya. Literasi keuangan didefinisikan sebagai kemampuan seseorang untuk mendapatkan, memahami dan mengevaluasi informasi yang relevan untuk pengambilan keputusan dengan memahami konsekuensi finansial yang ditimbulkannya.

Lusardi, (2013), literasi keuangan adalah keterampilan penting bagi pengambilan keputusan dan kesejahteraan selama siklus hidup. Klapper, Lusardi dan Panos, 2012 menyatakan bahwa individu dengan tingkat literasi keuangan yang lebih tinggi secara signifikan lebih mungkin untuk melaporkan lebih banyak pendapatan terpakai pada akhir bulan dan kapasitas pengeluaran yang lebih tinggi. Dan bahwa literasi keuangan yang lebih baik dapat melengkapi individu untuk menghadapi guncangan ekonomi makro.

\section{Financial Literacy dalam Perspektif Islam}

Dalam Literasi Keuangan syariah selain untuk memperluas dan meningkatkan pengetahuan dan pemahaman masyarakat dalam penggunaan produk dan jasa keuangan syariah juga diharapkan dapat mengubah prilaku masyarakat dalam 
mengelola keuangan secara lebih baik, mampu dan cerdas memilih investasi yang halal dan menguntungkan sesuai dengan syariah. Dengan demikian masyarakat dapat memperoleh pemahaman mengenai Lembaga Jasa Keuangan syariah serta produk dan jasa keuangan syariah, termasuk fitur, manfaat dan risiko, serta hak dan kewajiban terkait produk dan jasa keuangan syariah. Literasi Keuangan Syariah juga diharapkan mampu mendorong peningkatan pemanfaatan produk dan jasa keuangan yang sesuai dengan kebutuhan masyarakat muslim pada khususnya dan masyarakat Indonesia pada umumnya.

Ketidakmampuan seseorang dalam mengelola keuangan menyebabkan orang berperilaku boros dalam kehidupannya, padahal islam melarang untuk berlaku boros. Sebagaimana firman Allah Ta'ala dalam surat Al Isra ayat 26-27, "Dan berikanlah kepada keluarga-keluarga yang dekat akan haknya, kepada orang miskin dan orang yang dalam perjalanan dan janganlah kamu menghambur-hamburkan (hartamu) secara boros. Sesungguhnya pemboros-pemboros itu adalah saudara-saudara syaithan dan syaithan itu adalah sangat ingkar kepada Tuhannya." Diperkuat dengan surat Al Furqon ayat 67,'Dan orang-orang yang apabila membelanjakan (harta), mereka tidak berlebihan, dan tidak (pula) kikir, dan adalah (pembelanjaan itu) di tengah-tengah antara yang demikian."

Penegasan ini mensiratkan bahwa seorang muslim harus pandai mengelola uang pribadinya dengan cerdas. Al Qur'an diturunkan 14 abad yang lalu, dan sudah menegaskan pentingnya merencanakan keuangan agar bisa membelanjakan ditengahtengah antara keduanya (tidak berlebihan/ boros dan kikir).

\section{METODE PENELITIAN}

Penelitian ini menganalisis tentang pengaruh minat ibu-ibu rumah tangga dalam menyusun Perencanaan Keuangan Keluarga di Kota Pekanbaru. Yang menjadi variabel dalam penelitian ini adalah karakteristik keluarga sebagai variabel independen berupa pekerjaan ibu rumah tangga (X1) dan jumlah anak (X2), sedangkan minat membuat perencanaan keuangan keluarga $(Y)$ sebagai variabel dependen.

Penelitian ini menggunakan data primer yang meliputi jawaban responden atas kuesioner yang diberikan.Disamping itu juga digunakan data sekunder sebagai bahan 
penguat data dalam penelitian ini, berupa data jumlah Penduduk khususnya jumlah ibu rumahtangga yang ada di Kota Pekanbaru.

Populasi dalam penelitian ini adalah jumlah rumah tangga di Kota Pekanbaru sebesar 213.795 kepala keluarga. Dengan populasi sebesar 213.795 rumah tangga dan e sebesar 0,05 maka diperoleh sampel minimal sebesar 400 responden ibu rumah tangga. Sedangkan teknik pengambilan sampel dilakukan dengan metode proportionate stratified random sampling yaitu pengambilan sampel dari anggota populasi secara acak dan berstrata secara proporsional, dilakukan sampling ini apabila anggota populasinya heterogen.

\section{Rancangan Penelitian}

Penelitian ini menggunakan pendekatan Ilmu Manajemen yang memfokuskan pada bidang Manajemen Keuangan. Penelitian ini bersifat deskriptif dan kuantitatif. Penelitian deskriptif adalah penelitian yang bertujuan untuk memperoleh deskripsi tentang pengaruh karakteristik keluarga dengan indikator, tingkat pendidikan, jumlah anak dan jenis pekerjaan. Sifat penelitian kuantitatif pada dasarnya ingin menguji diterima atau tidaknya suatu hipotesis yang dilaksanakan melalui pengumpulan data di lapangan.

Berdasarkan uraian diatas maka dalam penelitian ini dapat dibuat kerangka pemikiran yang menunjukkan hubungan antar variabel yang akan diteliti yaitu variabel terikat Minat membuat Perencanaan Keuangan Keluarga atau variabel bebas (Y),yang terdiri dari empat indikator yaitu Rasa ingin tahu, kesadaran akan manfaat, Pencurahan waktu dan kekecewaan bila tidak membuat. Hubungan antar variabel tersebut diilustrasikan dalam Gambar 1 berikut ini:

Gambar 1 Kerangka pemikiran Pengaruh Karakteristik Keluarga terhadap Minat membuat Perencanaan Keuangan Keluarga. 


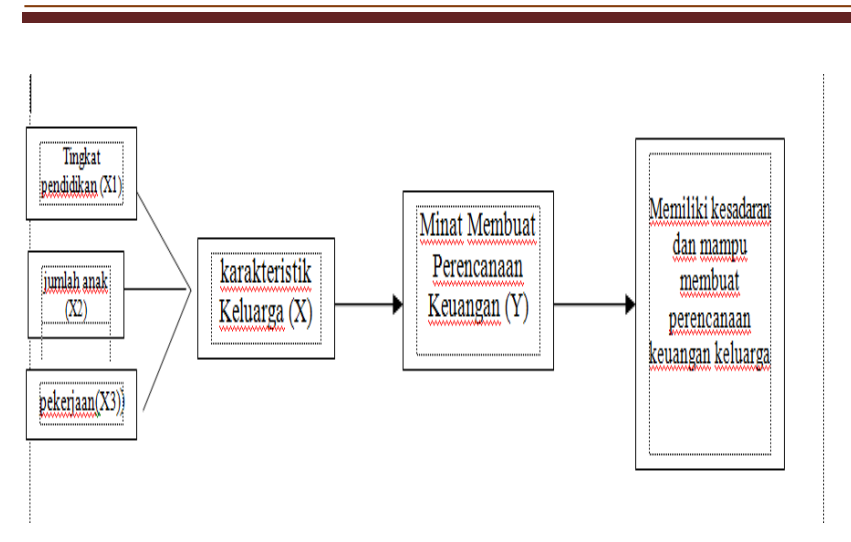

\section{Hipotesis :}

1. Diduga berdasarkan pekerjaan terdapat perbedaan minat membuat perencanaan keuangan keluarga pada ibu RT di kota Pekanbaru.

2. Diduga berdasarkan jumlah anak terdapat perbedaan minat membuat perencanaan keuangan keluarga pada ibu RT di kota Pekanbaru

\section{Analisis Data}

Pengumpulan data dalam penelitian ini dilakukan melalui kuesioner, oleh karena itu kesungguhan responden dalam menjawab pertanyaan merupakan hal yang penting. Maka dari itu penulis merasa perlu untuk melakukan uji validitas dan uji realibitas.

Nilai reliabilitas menunjukkan keseluruhan item pertanyaan yang diuji termasuk dalam kategori positif atau reliable negative atau tidak reliable. Uji reliable ini dilakukan hanya untuk variable yang diteliti yang datanya bersumber dari data primer melalui kuesioner dengan skala ordinal, sedangkan variable yang datanya berskala rasio tidak dilakukan uji reliabilitas lagi.

Uji validitas dilakukan untuk mengukur pernyataan yang ada dalam kuisioner. Suatu pernyataan dianggap sahih jika pernyataan tersebut mampu mengungkapkan apa yang diungkapkan atau yang ingin diukur. Suatu instrument pengukur dikatakan valid jika instrument tersebut dapat mengukur construct sesuai dengan yang diharapkan oleh peneliti. 
Uji validitas dalam penelitian ini dilakukan dengan menggunakan software SPSS. Berdasarkan menu yang terdapat dalam SPSS dipilih korelasi dari Pearson sehingga dapat diketahui nilai yang menunjukkan data yang termasuk dalam kategori positif atau valid dan negatif atau tidak valid.

Metode penelitian yang digunakan dalam penelitian ini adalah descriptive survey dan explanatory survey.Untuk mendapatkan gambaran perbedaan minat membuat perencanaan keuangan keluarga berdasarkan karakteristik keluarga di kota Pekanbaru maka digunakan pendekatan deskriptif dan verifikatif..

Pengujian hipotesis yang digunakan berupa analisis uji beda (chi square) analisis Pearson's $R$ untuk Nilai table dengan level of significant(a) sebesar $5 \% .=9,488$

\section{Gambaran Umum Responden}

Berdasarkan hasil survey yang penulis lakukan terhadap 400 orang responden yang tersebar pada 12 kecamatan di kota Pekanbaru maka diperoleh gambaran umum responden berdasarkan pekerjaan. Dalam hal ini peneliti mengidentifikasi data menjadi dua bagian yaitu responden yang bekerja dan yang tidak bekerja.

\section{Tabel 1: Jumlah Responden Berdasarkan Pekerjaan}

\begin{tabular}{|l|c|}
\hline Pekerjaan Responden & Frekuensi \\
\hline Tidak Bekerja & $167(42 \%)$ \\
\hline Bekerja & $233(58 \%)$ \\
\hline Jumlah & $\mathbf{4 0 0 ( 1 0 0 \% )}$ \\
\hline
\end{tabular}

Sumber : Data olahan, 2015

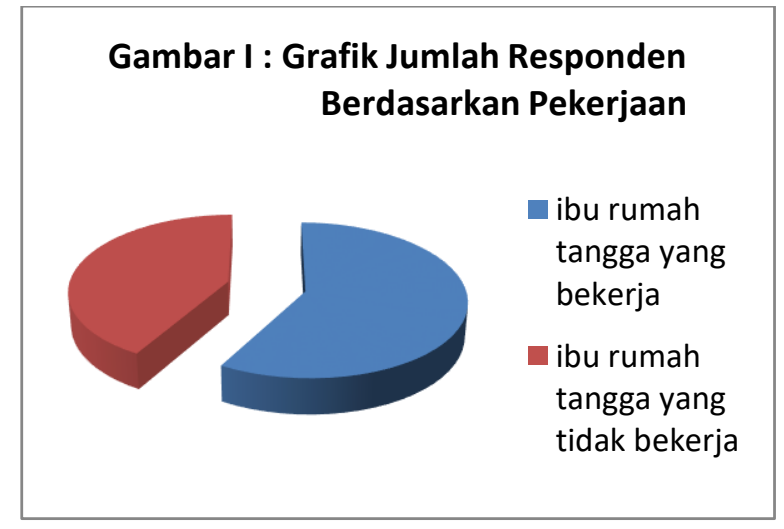

Sumber: Data olahan, 2015 
Berdasarkan data diatas dapat kita ketahui bahwa sebagian besar ibu rumah tangga yang menjadi responden dalam penelitian ini adalah ibu rumah tangga yang bekerja yaitu sebanyak 233 orang atau 58\% dan ibu rumah tangga lainnya sebanyak 164 orang atau $42 \%$ tidak memiliki pekerjaan. Hal ini menggambarkan bahwa saat ini ibu rumah tangga di Pekanbaru banyak yang mempunyai pekerjaan di luar rumah seperti menjadi, pegawai swasta, pegawai negeri, berprofesi sebagai guru, dosen, dokter bahkan berwiraswasta dan menjadi pengusaha.

Untuk jumlah responden berdasarkan jumlah anak dapat dilihat pada Tabel 2 berikut ini:

\section{Tabel 2 Jumlah Responden berdasarkan Jumlah Anak}

\begin{tabular}{|c|c|}
\hline Jumlah Anak Responden & Frekuensi \\
\hline$\leq 2$ orang & $257(64 \%)$ \\
\hline$>2$ orang & $143(36 \%)$ \\
\hline Jumlah & $\mathbf{4 0 0 ( 1 0 0 \% )}$ \\
\hline
\end{tabular}

Sumber : Data olahan, 2015

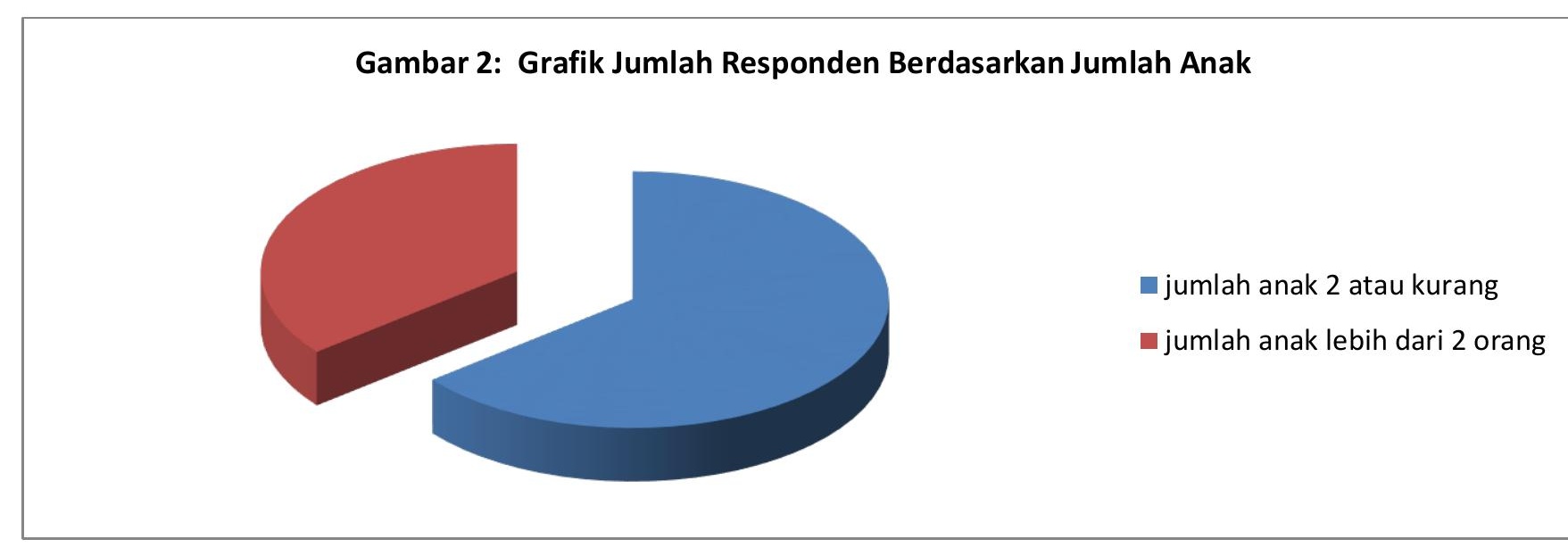

Sumber: Data olahan, 2015 
Seperti yang terlihat pada tabel 2 di atas diketahui bahwa terdapat 257 orang yang memiliki anak hanya 1 atau 2 orang dan yang memiliki anak lebih dari 2 orang sebanyak 143 orang responden.

Berdasarkan grafik diatas juga dapat disimpulkan bahwa sebagian besar responden atau $64 \%$ memiliki anak kurang atau sama dengan 2 orang dan $36 \%$ responden memiliki jumlah anak lebih dari dua orang. Hal ini menggambarkan bahwa dewasa ini para keluarga di Kota Pekanbaru cendrung memiliki jumlah anak yang lebih sedikit dibanding generasi sebelumnya.

Disamping komposisi data diatas dapat pula diidentifikasi karakteristik keluarga dengan komposisi jumlah responden berdasarkan jumlah anak dan pekerjaan, seperti yang terlihat pada Tabel 3 berikut ini :

Tabel 3: Komposisi Jumlah Responden Berdasarkan Jumlah Anak Dan Pekerjaan

\begin{tabular}{|l|l|l|l|}
\hline \multirow{2}{*}{ Jumlah anak } & \multicolumn{2}{|c|}{ Pekerjaan } & \multirow{2}{*}{ Total } \\
\cline { 2 - 4 } & \multicolumn{1}{|c|}{ Tidak Bekerja } & \multicolumn{1}{|c|}{ Bekerja } & \\
\hline$\leq 2$ & $82(49 \%)$ & $175(75 \%)$ & $257(64 \%)$ \\
\hline$>2$ & & & $143(36 \%)$ \\
\hline Total & $85(51 \%)$ & $58(25 \%)$ & \\
\hline
\end{tabular}

Sumber: Data olahan, 2015

Dari tabel di atas diketahui bahwa ibu rumah tangga yang bekerja dan memiliki jumlah anak kurang dari 2 orang sebesar $75 \%$ dan yang tidak bekerja sebesar 49\%. Ibu rumah tangga yang bekerja dengan jumlah anak lebih dari 2 orang sebesar $25 \%$ dan yang tidak bekerja sebesar $51 \%$. Jadi sebahagian besar responden adalah ibu rumah tangga yang bekerja dengan memiliki anak kurang dari 2 orang. Hal ini menggambarkan bahwa sebagian besar ibu rumah tangga yang bekerja cendrung memiliki anak lebih sedikit dibandingkan ibu rumah tangga yang tidak memiliki pekerjaan. 
Dari data dan uraian diatas maka dapat disimpulkan bahwa gambaran umum karakteristik keluarga di kota Pekanbaru ibu rumah tangganya rata rata memiliki pekerjaan atau profesi lainnya di luar rumah .Secara umum tingkat ekonomi keluarga dengan karakteristik ini cendrung lebih mapan karena penghasilan keluarga tentu lebih banyak dan hanya untuk membiayai keperluan jumlah anggota keluarga yang lebih sedikit.

\section{Pembahasan}

Tujuan Penelitian ini adalah untuk mengetahui apakah terdapat perbedaan minat membuat perencanaan keuangan keluarga menurut karakteristik keluarga di kota Pekanbaru. Berdasarkan tujuan tersebut maka untuk mengukur minat responden dalam membuat perencanaan keuangan keluarga dibangun sebuah konstruk dengan empat indikator yaitu rasa ingin tahu terhadap perencanaan keuangan, menyediakan waktu untuk melakukan perencanaan keuangan, kesadaran akan manfaat perencanaan keuangan, dan kecewa jika tidak melakukan perencanaan keuangan.

Setiap indikator diatas dikembangkan menjadi enam pernyataan berdasarkan elemen-elemen umum perencanaan keuangan keluarga dengan 5 skala jawaban menurut Likert,jadi total pernyataan dari kuesioner adalah 24 pernyataan dan ditambah dengan 4 pernyataan dengan bentuk pernyataan ya atau tidak.

\section{Analisis Frekuensi}

Dari hasil kuesioner yang dibagikan dilakukan analisa frekuensi maka dapat diketahui persentase terbesar dari pertanyaan-pertanyaan yang dipilih oleh responden ibu rumah tangga berdasarkan pekerjaan :

Tabel 4: Tabel Tanggapan Responden Terhadap Minat Membuat Perencananaan Keluarga berdasarkan Pekerjaan Ibu Rumah Tangga

\begin{tabular}{|c|c|c|c|c|}
\hline Pekerjanll & $\begin{array}{l}\text { Rasa Ingill } \\
\text { Tahll }\end{array}$ & $\begin{array}{c}\text { Menjediakall } \\
\text { Waktı }\end{array}$ & $\begin{array}{c}\text { Kesaddarall } \\
\text { akiall } \\
\text { Manffant } \\
\end{array}$ & $\begin{array}{c}\text { Kekecewaan } \\
\text { tidlak } \\
\text { Melakulkan }\end{array}$ \\
\hline Tildak Bekerja & $14,9 \%$ & $22,2 \%$ & $14,9 \%$ & $20 \%$ \\
\hline Bekerja & $85,1 \%(340$ & $77,8 \%$ & $85,1 \%$ & $80 \%$ \\
\hline
\end{tabular}

Sumber: Data olahan, 2017 
Berdasarkan pekerjaan responden didapatkan bahwa jawaban-jawaban yang dipilih oleh ibu rumah tangga yang bekerja memiliki rasa ingin tahu terhadap perencanaan keuangan sebesar $85,1 \%$ sedangkan yang tidak bekerja rasa ingin tahu terhadap perencanaan keuangan hanya sebesar 14,9\%. Untuk indikator minat mengenai menyediakan waktu untuk membuat perencanaan keuangan keluarga dari 400 responden yang memiliki pekerjaan sebesar $77,8 \%$, sedangkan yang tidak memiliki pekerjaan hanya sebesar $22,2 \%$. Ibu rumah tangga yang bekerja memiliki kesadaran akan manfaat perencanaan keuangan keluarga sebesar 85,1\% sedangkan yang tidak bekerja hanya sebesar 14,9\%. Merasakan kecewa jika tidak melakukan perencanaan keuangan keluarga bagi ibu rumah tangga yang bekerja sebesar $80 \%$ dan yang tidak bekerja sebesar $20 \%$.

Dari gambaran diatas diketahui bahwa ibu rumah tangga di Pekanbaru yang bekerja mempunyai minat yang sangat besar terhadap perencanaan keuangan keluarga dibanding ibu rumah tangga yang tidak bekerja.

\section{Pengujian Hipotesis dengan Analisa Chi Square}

Pengujian hipotesis dalam penelitian ini dilakukan dengan menggunakan menggunakan chi square. Uji hipotesis dengan level of significant (a) sebesar $5 \%$. Penelitian ini menggunakan program komputer SPSS 20.0 sebagai alat bantu untuk melakukan pengujian hipotesis, yaitu menguji ada tidaknya perbedaan minat membuat perencanaan keuangan keluarga berdasarkan pekerjaan (bekerja dan tidak bekerja) dan jumlah anak $(\leq 2$ dan $>2)$

Pengujian hipotesis tersebut dilakukan pada masing-masing indikator minat yaitu rasa ingin tahu terhadap perencanaan keuangan, menyediakan waktu untuk melakukan perencanaan keuangan, kesadaran akan manfaat perencanaan keuangan, dan kecewa jika tidak melakukan perencanaan keuangan. Kegiatan pengamatan telah dilakukan terhadap 400 responden dari 12 kecamatan yang ada di Pekanbaru. Hasil pengolahan data dari chi square untuk masing-masing indikator minat dapat dilihat berdasarkan tabel dibawah ini :

\section{Tabel 5: Analisa Chi Square}

Nilai chi square tabel dengan level of significant (a) sebesar $5 \% .=9,488$ 


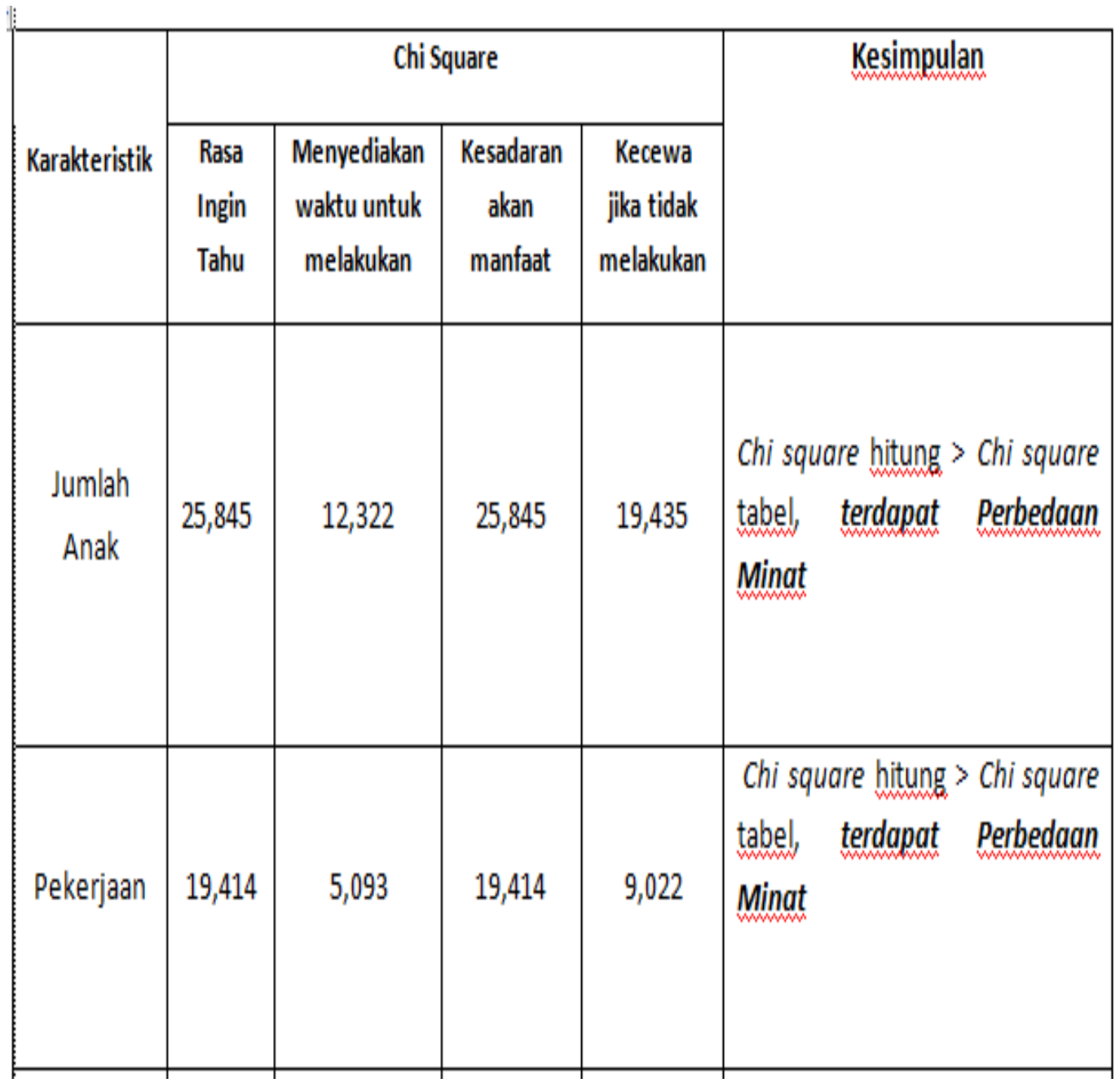

Sumber : Data olahan, 2015

Dari tabel diatas dapat diketahui hasil pengujian untuk hipotesis yang telah diajukan sebelumnya yaitu :

a. Hipotesis pertama (H1) : Berdasarkan jenis pekerjaan terdapat perbedaan minat membuat perencanaan keuangan keluarg pada ibu rumah tangga di Kota Pekanbaru.

Dari tabel 5 di atas diketahui bahwa berdasarkan pekerjaan, nilai chi square untuk rasa ingin tahu adalah sebesar 19,414>9,488, nilai chi square menyediakan waktu untuk melakukan perencanaan keuangan adalah sebesar 5,093 $<9,488$, nilai chi square kesadaran akan manfaat perencanaan keuangan 19,414 > 9,488 dan 
nilai chi square kecewa jika tidak melakukan perencanaan keuangan 9,022<9,488 , sehingga dapat disimpulkan bahwa hipotesis diterima, Berarti terdapat perbedaan pada indikator minat rasa ingin tahu terhadap perencanaan keuangan, menyediakan waktu untuk melakukan perencanaan keuangan, kesadaran akan manfaat perencanaan keuangan, dan kecewa jika tidak melakukan perencanaan keuangan antara ibu rumah tangga yang bekerja dan yang tidak bekerja.

Berdasarkan analisis frekwensi ibu rumah tangga yang bekerja cendrung lebih berminat untuk membuat perencanaan keuangan keluarga dibanding ibu rumah tangga yang tidak bekerja. Untuk keluarga dengan ibu bekerja tentu penghasilan atau pendapatan rumah tangga menjadi lebih besar pula yang apabila penghasilan tersebut tidak dikelola dengan baik maka dana yang diperoleh tidak termanfaatkan secara efisien dan efektif. Diterimanya hipotesis ini menunjukkan bahwa dengan penghasilan rumah tangga yang lebih besar kesadaran akan manfaat dan minat untuk membuat perencanaan keuangan juga semakin besar pula.

\section{b. Hipotesis kedua (H2) : Berdasarkan jumlah anak terdapat perbedaan minat membuat perencanaan keuangan keluarga pada ibu rumah tangga di kota Pekanbaru}

Nilai chi square hitung untuk Rasa ingin tahu adalah sebesar 25,845 yang berarti nilai ini >9,488, sedangkan nilai chi square yang diperoleh dari menyediakan waktu untuk melakukan perencanaan keuangan adalah sebesar 12,322 juga > 9,488, nilai chi square kesadaran akan manfaat perencanaan keuangan 25,845 dan nilai chi square kecewa jika tidak melakukan perencanaan keuangan 19,435.

Dengan demikian dapat disimpulkan bahwa hipotesis pertama diterima, yaitu terdapat perbedaan pada indikator minat rasa ingin tahu terhadap perencanaan keuangan, menyediakan waktu untuk melakukan perencanaan keuangan, kesadaran akan manfaat perencanaan keuangan, dan kecewa jika tidak 
melakukan perencanaan keuangan antara ibu rumah tangga yang jumlah anak $\leq$ 2 dan $>2$.

Hasil ini menunjukkan bahwa ibu rumah tangga di Pekanbaru yang jumlah anaknya kurang dari 2 orang cenderung lebih berminat terhadap perencanaan keuangan keluarga dibanding ibu rumah tangga yang jumlah anaknya lebih dari 2 orang. Dengan jumlah anak yang sedikit mereka memiliki lebih banyak waktu dan mempunyai minat yang lebih besar untuk membuat perencanaan keuangan keluarga. Salah satu caranya adalah mempersiapkan dana untuk biaya pendidikan dengan memiliki asuransi pendidikan atau tabungan untuk masa depan anaknya.

\section{KESIMPULAN DAN SARAN}

\section{a. Kesimpulan}

Berdasarkan analisis data dan hasil penelitian yang sudah diuraikan maka peneliti mengambil kesimpulan sebagai berikut:

1. Gambaran umun dari karakteristik keluarga di kota Pekanbaru adalah keluarga yang ibu rumahtangganya berpendidikan sarjana keatas, rata rata memiliki pekerjaan atau profesi lainnya diluar rumah dan rata-rata memiliki jumlah anak yang lebih sedikit hanya satu atau dua orang anak saja.

2. Hasil pengujian hipotesis juga menunjukkan bahwa terdapat perbedaan minat untuk membuat perencanaan keuangan keluarga antara ibu rumah tangga yang bekerja dengan ibu rumah tangga yang tidak bekerja.

3. Berdasarkan hasil pengujian hipotesis dengan analisis Chi Square diperoleh hasil bahwa, terdapat perbedaan minat dalam membuat perencanaan keuangan keluarga antara ibu rumah tangga yang memiliki anak dua orang atau kurang dengan ibu rumah tangga yang mempunyai anak lebih dari dua orang.

\section{b. Saran}

Berdasarkan survey dan hasil penelitian yang telah dijelaskan maka disarankan kepada masyarakat di Kota Pekanbaru khusunya ibu-ibu rumah tangga yang 
berperan sebagai manajer keuangan dalam keluarganya agar menambah pengetahuan dan wawasannya tentang financial literacy. Disarankan juga agar bersedia meluangkan waktu untuk membuat perencanaan keuangan keluarga agar sumber penghasilan rumah tangga atau dana yang tersedia dapat dialokasikan secara efektif dan efisien. Financial literacy yang diberikan kepada keluarga di Pekanbaru perlu disesuaikan dengan karakteristik keluarga yang ada, sehingga informasi yang diberikan mudah dimengerti dan dipahami serta mampu diterapkan khususnya bagi ibu-ibu rumah tangga yang berperan dalam mengelola keuangan keluarga.

\section{DAFTAR PUSTAKA}

Adler H Manurung.2009. Successful Financial Planner A Complete Guide, Grasindo, Jakarta.

Annamaria Lusardi, (2008). Household Saving Behavior: The Role of Financial Literacy, Information, and Financial Education Programs (Dartmouth College and NBER).

Brandon, D. P. \& Smith, C. M. 2009. Prospective Teachers' Financial Knowledge and Teaching Self-Efficacy. Journal of Family \& Consumer Sciences Education, 27(1).

Byrne, A. 2007.Employee saving and investment decisions in defined contribution pension plans: survey evidence from the U.K. Financial Services Review $16,19-40$

Chen, H. \& Volpe, R. P. 2002.Gender differences in personal financial literacy among college students.Financial services review11 289-307

Cude, B. J, Lawrence, F. C, Lyons, A. C, Metzger, K, LeJeune, E, Marks, L. \& Machtmes, K. 2006. College Students and Financial Literacy: What They Know and What We Need to Learn. Eastern Family Economics and Resource Management Association-Conference

Departemen Pendidikan Nasional, 2008. Kamus Besar Bahasa Indonesia Edisi 4, PT, Gramedia Pustaka Utama, Jakarta. 
Danes, S. M. \& Haberman, H. R. 2007.Teen Financial Knowledge, Self-Efficacy, and Behavior: A Gendered View. Financial Counseling and Planning Volume 18 , Issue 2

Diana Coben, Margareth Dawes, and Nirmala Lee. 2005. Financial Literacy Education\& Skill of life, Institute of University of London.

Ghozali, I 2007, Aplikasi Analisis Multivariate dengan Program SPSS, Edisi Keempat,Semarang, Badan Penerbit Universitas Diponegoro.

Lawrence Gitman, 2002.Principle of Finance, (11th ed). Prentice Hall, New Jersey

Senduk, Safir. 2009. Seri Perencanaan Keuangan, Mengelola Keuangan Keluarga. PT. Elex Media Komputindo. Jakarta.

Sonia Marcolin \& Anne Abraham. 2006. Financial Literacy Reseach : CurrentLiterature and Future Opportunities, 3rd International Conference of ContemporaryBusiness.

Yohnshon.2004. Peran Universitas di Surabaya dalam Meningkatkan Jumlah Keluarga Mapan di Surabaya. Jurnal Manajemen \& Kewirausahaan Vol. 6, No. 1, Maret 2004: 54 - 71 Ifakultas Ekonomi, Universitas Kristen Petra.

William Tanuwidjaja. 2002. 8 Intisari Kecerdasan Finansial Edisi Revisi, MediaPressindo Jakarta. 